\title{
Weight-Related Sport Motives and Girls' Body Image, Weight Control Behaviors, and Self-Esteem
}

\author{
A. P. (Karin) de Bruin • Liesbeth Woertman • \\ Frank C. Bakker • Raôul R. D. Oudejans
}

Published online: 15 November 2008

(C) The Author(s) 2008. This article is published with open access at Springerlink.com

\begin{abstract}
Research has shown that exercise for weight control is associated with disordered eating indices in older adolescent or adult exercisers in fitness centers. This study examined whether these relationships could be replicated in a more general sample of 140 Dutch adolescent girls between 13 and 18 years old. Questions about sport participation, items from the Multidimensional Body Image Questionnaire and BULIT-R, the Contour Drawing Rating Scale and Rosenberg Self-Esteem Scale were completed. The girls were categorized as sport-participants with or without weight-related motives or as non-sport-participants. Weight-related sport participation was significantly associated with body dissatisfaction, more weight control and lower self-esteem. In conclusion, it is important to consider motives for sport participation when studying relationships between sport and well being.
\end{abstract}

Keywords Adolescents · Body dissatisfaction .

Eating disorders $\cdot$ Exercise motivation $\cdot$ Sport participation

\section{Introduction}

Although participation in sport and exercise may have various positive effects, such as weight loss, lower body dissatisfac-

A. P. (Karin) de Bruin $(\bowtie) \cdot$ F. C. Bakker $\cdot$ R. R. D. Oudejans

VU University Amsterdam, Research Institute MOVE,

Faculty of Human Movement Sciences,

Van der Boechorststraat 9,

1081 BT Amsterdam, The Netherlands

e-mail: k.debruin@fbw.vu.nl

e-mail: k.debruin@gmail.com

\section{Woertman}

University of Utrecht, Department of Clinical Psychology,

Heidelberglaan 1,

3584 CS Utrecht, The Netherlands

e-mail: E.M.Woertman@fss.uu.nl tion, fewer eating problems, and higher self-esteem (see Hausenblas and Fallon 2006; Hausenblas and SymonsDowns 2001; Loland 1998), there is also strong empirical evidence that in particular cases it may lead to more eating disorder symptomatology. For example, in aesthetic, weightclass, or endurance sports, particularly when performing at the elite level, more frequent dieting and other disordered eating related symptoms were found (De Bruin et al. 2007; Smolak et al. 2000; Sundgot-Borgen and Torstveit 2004). In addition, several studies in non-sport fitness and exercise activities have found that the presumed mental benefits of sport participation tend not to be experienced by individuals who are motivated to exercise for weight control or appearance-related reasons (Ingledew and Sullivan 2002; Strelan et al. 2003). So far, research has been limited to regular exercisers inside fitness centers only, and older adolescent or adult samples primarily coming from Australia (e.g., Furnham et al. 2002; Strelan et al. 2003), UK (e.g., Ingledew and Sullivan 2002), or US (e.g., Hubbard et al. 1998; McDonald and Thompson 1992).

The aim of the present study was to investigate whether the established relationships between weight-related exercise motivation and the above mentioned disordered eating correlates could be replicated in and generalized to a more general sample of female adolescent sport participants outside the area of fitness centers. In a sample of Dutch adolescent girls between 13 and 18 years of age, sport participants who were motivated by weight-related reasons were compared with sport participants who were not motivated by weight-related issues and girls who did not participate in sport. Possible differences were examined on relevant variables such as dieting and weight control behaviors, body image and self-esteem.

Previous research has shown that exercising to lose weight is a common practice, and that weight loss is one of the main reasons cited by women but not by men for engaging in physical activity (McDonald and Thompson 1992; Silberstein 
et al. 1988). These gender differences are already present in adolescence, as girls aged 16-18 years exercised more for weight loss, while the boys' reasons for exercising were largely related to physical fitness (Furnham et al. 2002).

Exercising for health, fitness, or enjoyment, also referred to as functional exercising, has been associated with a decrease in overall eating disorder symptomatology and improved body satisfaction (DiBartolo and Shaffer 2002; Tiggemann and Williamson 2000). In contrast, so called body-related exercising for weight loss, body tone, or attractiveness has been shown to be related to disturbed eating, body dissatisfaction, and lower self-esteem (Cash et al. 1994; McDonald and Thompson 1992, Silberstein et al. 1988; Smith et al. 1998; Strelan et al. 2003; Tiggemann and Williamson 2000). Hubbard et al. (1998) concluded that female exercisers who exercise particularly for burning calories or losing weight indicated the greatest disturbance on these areas.

A limitation of the studies above is that mainly adult or undergraduate student samples were studied. Tiggemann and Williamson (2000) who investigated exercisers between 16 and 60 years old only found significant negative relationships with body satisfaction and self-esteem for the group of younger women below 21 years, suggesting that girls and women between 16 and 21 years of age are an important target group in investigating body image-related issues. Furnham et al. (2002) focused explicitly on adolescents of 16-18 years old and found that body-related exercising appeared to be a significant predictor for body dissatisfaction and disturbed eating in this population. Since the physical self-concept scores of Norwegian girls went down dramatically in the transition from elementary to secondary school (Klomsten et al. 2004), it seems particularly important to also focus on younger female secondary school students below 16 years of age.

A second limitation of the studies cited above is that they only included regular exercisers inside fitness centers, a limited and possibly selective sample. Generally more body-related motives are found in these so-called "nonsport fitness activities" (Frederick and Ryan 1993) that are typically practiced to become in shape, referring to both physical condition and, more importantly, to an aesthetic proportionality of body fat and muscularity (Van Hilvoorde 2008). Moreover, fitness centers can be seen as environments containing a large number of objectifying features such as mirrors and revealing clothing, and reflecting a body culture that is characterized by an increased focus on bodily appearance, interpersonal comparisons, and observations (Prichard and Tiggemann 2005; Sassatelli 1999; Strelan et al. 2003). According to Objectification Theory (Frederickson and Roberts 1997), being exposed to these kinds of body objectification will result in self-objectification, as women and girls gradually internalize this observer's perspective and see themselves as "an object" for others to view and evaluate on the basis of their appearance. Women and girls high on self-objectification are also more likely to exercise for body-related motives and to have a reduced body satisfaction and self-esteem (Strelan et al. 2003). However, as it was unclear whether attending fitness centers caused selfobjectification or that it was merely a result, Strelan et al. (2003) recommended investigating the experiences of other populations, such as women whose exercise outlet is primarily playing sport and who may not experience the same degree of body objectification.

Furthermore, nearly all conducted research in this area has been executed in non-European countries. These American (Nowak 1998; Silberstein et al. 1988; Wardle et al. 2006) and Australian studies (Middleman and Durant 1996; Middleman et al. 1998) point towards high percentages of adolescent women who worry deeply about weight and body image issues, attempting to lose weight by exercise or other methods. A validation study for the Dutch version of the Eating Disorder Inventory provided us with some data about eating disorder symptomatology in a Dutch sample compared to a North-American sample, indicating lower scores for Dutch high school girls on body dissatisfaction and a lower drive for thinness in Dutch college girls (Van Strien and Ouwens 2003). Cross-cultural European research concluded that preoccupation with weight seemed to be less prevalent in the Netherlands even in comparison to other, more central or southern parts of Europe (Waldherr et al. 2008). Nevertheless, in the Netherlands, as in most countries, the prevalence of overweight and obesity in children and adolescents is increasing rapidly (Hirasing et al. 2001). Public authorities in all Northern European countries have increased their focus on risk factors for and consequences of overweight, giving people the message that they need to watch their weight or that they should lose weight. Possible consequences of this increased focus related to the prevalence of eating disorder symptomatology are not known (Torstveit 2004). In sum, it seems justified to conclude that cultural differences exist in this area (Van Strien and Ouwens 2003) and that a diversity of cultural samples should be studied.

The present study therefore focused on the relationships of motivation for sport activities with body image, dieting behaviors, and self-esteem in a more general sample of Dutch female secondary school students between 13 and 18 years old. Weight-related sport participation, primarily for reasons of burning calories or weight control became the main focus of our study as Hubbard et al. (1998) found that these weight-related motives were linked to the greatest disturbance with regard to eating, body satisfaction and self-esteem. The variables body image dissatisfaction, weight concerns, and actual dieting behavior are known as important risk factors of eating disorders (Jacobi et al. 2004; Shisslak and Crago 2001); consequently, they are 
included in the present study. Body image is seen as a multidimensional concept (Gardner 2001) where body image dissatisfaction refers to "dissatisfaction with one's body size, shape or some other aspect of body appearance" (Gardner 2001, p. 193). This makes clear that a range of measures is needed to cover the various body image dimensions. Individuals with a negative body image often worry about their weight, are afraid to gain weight and therefore diet more often (Killen et al. 1996). Exercise for weight control is an increasingly popular dieting method in this respect, particularly among female adolescents (Middleman and Durant 1996; Middleman et al. 1998; Nowak 1998).

When participants are actually overweight and display a higher body mass index (BMI), participating in sport for weight-control could be considered more healthy and appropriate than when normal or underweight individuals display a weight-related motive for their sport activities. As BMI is a predictor of adolescent women's desire to reduce weight (Ingledew and Sullivan 2002) and also relates to body satisfaction, eating attitudes, dieting, and exercise (Crissey et al. 2006; Furnham et al. 2002; Hausenblas and Fallon 2006; Middleman et al. 1998; Torstveit 2004), it may confound our research findings. A higher BMI may result in a higher dissatisfaction with one's body, more dieting and possibly a higher prevalence of disordered eating, as well as more weight-related exercise. To adjust for actual body composition when examining associations between body image and sport, BMI was taken as a covariate in our analyses. To be able to control for other possible confounding effects as well, the groups were also compared on the demographic background variables educational level and age, and the sport-specific variables sport type, level of sport and hours of sport participation with chi-square analyses (education, sport type, sport level) or one-way analyses of variance (ANOVAs) (age, BMI, sport hours). An increased age, for example, could account for some of the increased prevalence of disordered eating indices due to the simple fact that older girls have been exposed to certain risk factors for a longer period (Torstveit 2004). When differences were found between the sub groups on these demographic or sport-specific variables (see section Results), those variables were taken as covariates to control for potentially confounding effects.

Several (ANCOVAs) were, therefore, used to analyze the dependent variables weight characteristics, multidimensional body image, dieting and weight control behaviors, and self-esteem, while age and BMI were taken as covariates. Post-hoc contrast analyses were done with weight-related sport participants contrasting not-weight-related sport participants and non-participants. In line with the exercise studies discussed above, we hypothesized that girls participating in sport out of weight-related motives would have a more negative body image than sport participants with not- weight-related motives, or than girls not participating in sport. In addition, we expected the first group to report significantly more dieting and weight control behaviors, as well as a lower self-esteem. In sum, the first hypothesis was that girls participating in sport out of weight-related motives would have a larger relative weight discrepancy, a higher score for perceived shape (read: more fat), a larger body figure discrepancy score, and a lower (read: more negative) perceived body appearance and face appearance than notweight-related sport participants and non-participants. The second hypothesis was that weight-related sport participants would report a higher dieting frequency, a higher weight control index score and higher purge index score than notweight-related sport participants and non-participants. The third hypothesis was that weight-related sport participants would score lower on self-esteem than sport participants with not-weight-related motives, or than girls not participating in sport.

\section{Method}

\section{Participants}

Participants were 140 girls, ranging in age from 1318 years, from two schools for secondary education in the centre of the Netherlands. From these schools several classes and different levels of the Dutch education system were included. The mean age of the girls was 15.3 years $(\mathrm{SD}=1.1)$.

\section{Procedure and Ethics}

The participants were approached through their teachers, who asked them to participate as a non-athlete control group in a larger study on the effect of elite aesthetic sport participation on body image and dieting. Part of this sample of 140 female adolescent schoolgirls acted as the control group in a larger study where they were compared with elite and non-elite gymnasts on dieting and body image (see De Bruin et al. 2007).

The girls were told that participation was voluntary and strictly anonymous; everyone agreed to participate. Written informed consent was obtained from the girls and their parents. Data collection occurred in the classroom with only the researcher (first author) present in order to give all the pupils similar instructions, to answer questions and to reduce any influence of the teachers. It took the participants approximately 30 to $40 \mathrm{~min}$ to fill in the questionnaires. Two questionnaires were incomplete and excluded from the present study. The research design was reviewed and approved by the Ethics Committee of the Faculty of Human Movement Sciences at the VU University Amsterdam. 


\section{Measure}

The following questionnaires were included in the present study:

\section{Sport Participation}

The girls were asked to report the main and side sports in which they participated. They were explicitly instructed to think about sport participation in their leisure time and not to include the compulsory physical education lessons at school. Afterwards, the sports were categorized into technical, endurance, aesthetic, weight class, ball-game sports types, and non-sport fitness activities, as this classification has previously been used when investigating disordered eating (see Sundgot-Borgen and Torstveit 2004). In endurance sports, such as cycling, track-and-field middle, and long distance running, and outside exercising on one's own such as jogging or rollerblading, the main focus is on aerobic endurance training, while sports with weight-class requirements (e.g., judo, lightweight rowing) were classified as weight-class sports. In aesthetic sports, for example gymnastics and dance, thinness and leanness are considered to be important and the most important aspect is the subjective evaluation by judges of competitive or artistic performance. Non-sport fitness activities included all exercise activities within fitness centers, such as fitness, aerobics, and steps. In addition, participants had to report the level of sport participation (elite, non-elite competitions, or recreational) and the amount of time (in minutes) spent on weekly training, and competition. Finally, the participants were asked if they had ever exercised or participated in sport with the specific purpose of burning extra calories or controlling weight, and if so, how often this occurred in the past 3 months. The sport participants were then categorized into two subgroups, namely sport participants with a weight-related sports motive, from now on referred to as weight-related sport participants, and not-weightrelated sport participants. Following Hubbard et al. (1998), weight-related sports motive was defined as sport participation or exercising with the specific purpose of burning extra calories or controlling weight, on a regular base (at least once a week) in the past 3 months (see Hubbard et al. 1998; Mond et al. 2004). The criterion of weekly frequency was added, because we only wanted to include those girls for whom weight-related sport participation was an important, recent, and repetitive activity rather than just a single one-time or past occurrence into the sub group of weight-related sport participants. Those who reported weight-related sport activities less than once a week in the past 3 months and, as a result, did not meet the weekly criterion were included in the group of not-weight-related sport participants.

\section{Participant Weight Characteristics}

Participants were asked to report their current height (in $\mathrm{cm}$ ) and weight (in $\mathrm{kg}$ ). With the self-reported height and weight figures, the Body Mass Index was calculated (BMI = weight in $\mathrm{kg} /$ height in $\mathrm{m}^{2}$ ). In addition to the actual weight, participants were asked to report their desired (ideal) weight (in $\mathrm{kg}$ ). Relative 'weight discrepancy' (WD) was computed by subtracting the actual weight from the ideal weight, divided by the actual weight and multiplied by 100 (De Bruin et al. 2007).

\section{Body Image}

Body image was measured with the Short Version of the "Multidimensional Body Image Questionnaire", which has been used in various samples of adolescents and adults (Woertman 1994). This self-report questionnaire is designed to assess the perceived and social components of the image of the face and body, consisting of items that were measured on a nine-point Likert scale or with report marks on a tenpoints scale ranging from 1 (very bad) to 10 (excellent) (see also Appendix). In the present study, the factor analysis was performed by means of principal component method of extraction with Kaiser's criterion (Eigenvalue over 1) and varimax rotation. One analysis was carried out on ten items measuring perceptions of one's own body and face (perceived component) as well as the perceived opinion of other girls and boys (social component). The data were considered to be suitable for factor analysis as the correlation matrices showed multiple correlations of $r=.3$ or higher, the Bartlett's tests of sphericity were significant at $p<.05$, and the KaiserMeyer-Olkin values exceeded the recommended value of .6 (Kaiser 1970, 1974 in Pallant 2005). The analysis revealed the presence of two components, explaining $76 \%$ of the total variance of body image, with all appropriate items clearly loading on the accompanying factor with values of .73 or higher, replicating the original results (Woertman 1994). The components "perceived facial appearance" and "perceived body appearance" were identified, both running from negative to positive and both consisting out of five items. Scores were obtained by dividing the sum of the item-scores by the total number of items on the scale. In addition, several reliability analyses were performed to determine internal consistency in Cronbach's alphas of the scales. Cronbach's alpha coefficients were .90 for "perceived facial appearance", and .93 for "perceived body appearance". In addition, one separate nine-point Likert-item measured perceived body shape from 1 (too thin) to 9 (too fat). According to test instructions, a score of five should be regarded as being satisfied, while a score above five would indicate perceiving oneself as too fat and below five as too thin. Correlation between this item 'perceived body shape' with relative weight discrepancy (WD) was strong with $r=-.67, p<.001$. 


\section{Body Dissatisfaction}

One of the most widely adopted valid measures of body dissatisfaction is the discrepancy obtained by measuring how individuals perceive their actual body shape compared to their idealized body shape. Several versions have been described of figural stimuli scales that range in discrete number of figures between five and 12 (Gardner 2001); in the present study five figures of the Contour Drawing Rating Scale were selected (Thompson and Gray 1995). Participants were asked to choose the figure "they think they are" (actual body shape) and the figure "they would like to be" (ideal body shape). Larger differences between participants' actual and ideal body-shape indicated greater body dissatisfaction (DiBartolo and Shaffer 2002); the score zero indicated that no Body Shape Discrepancy (BSD) was found, while a negative score meant girls desired a thinner body. Correlation between this BSD score with the item 'perceived body shape' of the Multidimensional Body Image Questionnaire was strong with $r=-.71$, inspiring confidence in using this one item.

\section{Weight Control Behaviors}

First, the frequency of dieting and other weight control behaviors was measured on a nine-point Likert-scale, running from 1 (never) to 9 (always) (Woertman 1994) with the following item: "Are you trying to lose weight?" (Wardle et al. 2006; Woertman 1994) from now on abbreviated and referred to as "dieting frequency" (see also De Bruin et al. 2007). Second, five items of the Bulimia Test-Revised (BULIT-R) (Thelen et al. 1991) provided specific information on the use of the following weight control behaviors: exercising in order to burn calories, fasting/strict dieting, self-induced vomiting, use of diet pills or diuretics, and use of laxatives or suppositories (see also Appendix). Vincent et al. (1999) have documented validity data among adolescent girls and report good reliability and adequate concurrent validity of the BULIT-R. Factor analysis on these weight control behaviors in the present study showed that self-induced vomiting, diuretics/diet pills, and laxatives/suppositories loaded together on one factor, clearly representing a common underlying theme of purging methods that are commonly used in order to lose weight very rapidly. These results are consistent with what is theoretically known about eating disorders and also confirm what is found in other studies (Engel et al. 2003). Subsequently, a "purge index score" was constructed (Engel et al. 2003), by adding the number of purging methods the girls had used, varying from zero to three. In spite of its Cronbach's alpha of .70, the purge index was retained because the lower internal consistency may be readily explained, as in practice using one purging method will not always be accompanied by another one. In addition to the purge index, a total weight control index score was constructed by adding up the number of all weight control methods ever used (see De Bruin et al. 2007), which varied from zero to five. Correlation between this weight control index score and one-item measure "dieting frequency" was strong with $r=.65, p<.001$.

\section{Self-Esteem}

Self-esteem was measured with the Dutch translation by Van Son (Woertman 1994) of the Rosenberg Self-Esteem Scale (SES; Rosenberg 1989). The original sample for which the scale was developed in the 1960s consisted of high school juniors and seniors. Ten items measure self-acceptance and self-worth, and are rated on a five-point Likert-scale ranging from 1 (strongly disagree) to 5 (strongly agree). Scoring procedures are generally executed one-dimensionally by adding up all items, which was followed in the present study with scores ranging from 10 to 50 . A higher score means more self-esteem. The scale generally has high reliability: test-retest correlations are typically in the range of .82 to .88 , and Cronbach's alphas for various samples are in the range of .77 to .88 (Blascovich and Tomaka 1993), and was .85 in the present study.

\section{Results}

Regarding sport participation, 24 out of 140 girls (17.1\%) reported no participation in any sport, while 116 girls $(82.9 \%)$ indicated to participate in sports; 51 of them (36.3\% of the total sample) practiced more than one sport. The most reported sports were dance, field hockey, non-sport fitness activities, volleyball, tennis, and jogging; ball games and aesthetic sports turned out to be the most popular sport types. A total of 40 girls were classified as weight-related sport participants, as they were physically active with the specific purpose to burn extra calories or control their weight at least once a week in the past 3 months. In sum, the girls were categorized into three groups: 24 non-participants (17.1\%), 40 weight-related $(28.6 \%)$ and 76 not-weightrelated $(54.3 \%)$ sport participants (see Table 1).

While no significant differences were found on the chisquare analysis of the educational level of the three groups, $\chi^{2}(4, N=140)=5.518, p=.164$, the one-way analyses of variance (ANOVAs) showed significant differences in age, $F(2,137)=5.689, p<.01$ (see Table 1) and BMI, $F(2,134)=$ $7.480, p<.01$ (see Table 2). Post hoc analyses showed that weight-related sport participants were slightly older and had a higher average BMI $(M=21.3 ; \mathrm{SD}=2.6)$ than the not-weightrelated participants $(M=19.5 ; \mathrm{SD}=2.4)$ and non-participants $(M=19.7 ; \mathrm{SD}=1.7)$. Subsequently, age and BMI were taken as covariates in subsequent analyses. Furthermore, the subgroups weight-related and not-weight-related sport partic- 
Table 1 Characteristics sport participation and background (percentages or SD in parentheses).

\begin{tabular}{llll}
\hline & Non-participants $(n=24)$ & Not-weight-related $(n=76)$ & Weight-related $(n=40)$ \\
\hline Average age (in years) & $15.17(.82)^{*}$ & $15.13(1.11)^{*}$ & $15.78(.89)$ \\
Average training hours & 0 & $4.1(3.36)$ & $3.46(2.6)$ \\
Main sports & - & $10(13.2 \%)$ & $3(7.5 \%)$ \\
Endurance & - & $16(21.1 \%)$ & $13(32.5 \%)$ \\
Aesthetic & - & $8(10.5 \%)$ & $4(10 \%)$ \\
Weight class & - & $37(48.7 \%)$ & $12(30 \%)$ \\
Ball-game & - & $5(6.6 \%)$ & $8(20 \%)$ \\
Non sport fitness activities & - & $3(4.1 \%)$ & - \\
Level of participation: & - & $26(35.1 \%)$ & $8(20 \%)$ \\
Elite & - & $45(60.8 \%)$ & $32(80 \%)$ \\
Non-elite competitions & - & & \\
Recreational & & & \\
\hline
\end{tabular}

${ }^{*} p<.05$; post-hoc comparison with contrast weight-related sport-participants

${ }^{a}$ No significant differences were found on the chosen type of main sports between weight-related and not-weight-related sport participants. Also, when participation in non-sport fitness activities was compared with the other sport activities combined, no significant differences were found, $\chi^{2}(1, N=116)=3.491, p>.05$

ipants were compared on several sport-related variables; chisquare analyses of sport type and level of participation were used in addition to an ANOVA of the weekly time they participated in sports. Although it seemed as if more weightrelated sport participants chose non-sport fitness activities as their main sport than not-weight-related sport participants, the difference did not reach the $p<.05$ significance level (see Table 1), $\chi^{2}(4, N=116)=8.507, p=.075$. Finally, no significant differences were found on the level of sport participation $\chi^{2}(2, N=114)=5.031, p=.081$, nor in weekly time spent on sport activities, $F(1,112)=1.1, p=.296$.

To test our hypotheses, the main dependent variables were analyzed with several one-way analyses of covariance
(ANCOVAs) with age and BMI as our covariates. In Table 2, the average scores of our main dependent variables are shown. With respect to the first hypothesis, where we expected differences on the body image measures, significant overall group effects were found on perceived body shape, $F(2,131)=$ $5.487, p<.05$, body figure discrepancy, $F(2,129)=4.638$, $p<.05$ and perceived body appearance, $F(2,123)=4.998$, $p<.01$, while no significant group effects were found on relative weight discrepancy, $F(2,125)=1.551, p=.216$ and perceived face appearance, $F(2,120)=1.258, p=.288$. Regarding the second hypothesis concerning differences on the measures of weight control, significant differences were found on dieting frequency, $F(2,131)=15.24, p<.001$, weight

Table 2 Average scores on weight characteristics, body image, weight control and self-esteem (SD in parentheses) with covariates BMI and age.

\begin{tabular}{|c|c|c|c|}
\hline & Non-participant $(n=24)$ & Not-weight-related $(n=76)$ & Weight-related $(n=40)$ \\
\hline BMI & $19.73(1.67)^{*}$ & $19.53(2.44)^{*}$ & $21.3(2.6)$ \\
\hline Relative weight discrepancy & $-2.25(6.70)$ & $-2.41(6.70)$ & $-7.26(5.92)$ \\
\hline Perceived body shape $^{\mathrm{a}}$ & $5.61(1.12)^{*}$ & $5.69(1.35)^{*}$ & $6.93(1.43)$ \\
\hline Body figure discrepancy ${ }^{\mathrm{b}}$ & $-.28(.69)^{*}$ & $-.32(.68)^{*}$ & $-.96(.81)$ \\
\hline Perceived body appearance $^{a}$ & $6.81(1.07)^{*}$ & $6.34(1.22)^{*}$ & $5.53(1.57)$ \\
\hline Perceived face appearance ${ }^{a}$ & $6.46(1.40)$ & $6.49(1.02)$ & $6.18(1.10)$ \\
\hline Dieting frequency $^{\mathrm{a}}$ & $2.26(1.45) *$ & $3.14(2.41)^{*}$ & $5.65(1.90)$ \\
\hline Weight control index ${ }^{\mathrm{c}, \mathrm{f}}$ & $.74(1.10)^{*}$ & $.47(.80)^{*}$ & $1.88(1.09)$ \\
\hline Purge index ${ }^{\mathrm{d}}$ & $.22(.671)$ & $.04(.259)^{*}$ & $.43(.813)$ \\
\hline Self-esteem ${ }^{\mathrm{e}}$ & $37.59(6.01)^{*}$ & $37.23(5.7)^{*}$ & $33.97(6.4)$ \\
\hline
\end{tabular}

When all analyses were repeated without the girls participating in non-sport fitness activities included, similar results were found, $F \mathrm{~s}(2,100)>$ $3.127, p \mathrm{~s}<.05$.

${ }^{*} p<.05$; post-hoc comparison with contrast weight-related sport-participants

${ }^{a}$ Scale (1-9); for average perceived body and face appearance, scale (1-9.2)

${ }^{\mathrm{b}}$ Scale $(-4-+4)$

${ }^{c}$ Scale $(0-5)$

${ }^{\mathrm{d}}$ Scale (0-3)

${ }^{\mathrm{e}}$ Scale (10-50)

${ }^{\mathrm{f}}$ When weight-related sport was excluded from the weight control index, similar results were found, $F(2,127)=6.326, p<.01$ with weight-related sport participants scoring higher than not-weigh-related sport participants or non-participants $\left(p<.01, p<.05 ; \eta^{2}=.091\right)$ 
control, $F(2,132)=21.106, p<.001$ and purging, $F(2,132)=$ $4.423, p<.05$. For the third hypothesis on self-esteem, significant group differences were found as well, $F(2,130)=$ $4.517, p<.05$. Covariate effects were found for BMI on all variables, $F \mathrm{~s}(1,123-131)>25.652, p \mathrm{~s}<.001$, except for perceived face appearance, $F(1,120)=.156, p=.693$, weight control, $F(1,128)=3.334, p=.070$, purging $F(1,128)=1.705$, $p=.194$, and self esteem, $F(1,130)=.078, p=.78$. No significant effects were found for covariate age, $F \mathbf{s}(1,123-$ $132)<1.744, p s>.424$. As was expected, it seems that the group of weight-related sport participants scored more negative on the various body image measures, higher on the weight control measures, and lower on self-esteem.

To confirm this, post-hoc contrast analyses were done with weight-related sport participants contrasting not-weightrelated sport participants and non-participants. Regarding our first hypothesis on body image, the results showed that compared to both not-weight-related sport participants and non-participants, weight-related sport-participants had a significantly larger perceived shape $\left(p<.01, p<.01 ; \eta^{2}=.077\right)$, a larger body figure discrepancy $\left(p<.01, p<.05 ; \eta^{2}=.007\right)$ and a more negatively perceived body appearance $(p<.05, p<.01$; $\eta^{2}=.075$ ). As expected, weight-related sport-participants perceived their body shape as more fat, were more dissatisfied with their body figure and perceived their bodily appearance as less beautiful. Second, as hypothesized, they also reported higher dieting frequency $\left(p<.001, p<.001 ; \eta^{2}=.189\right)$, and had a higher weight control index score $(p<.001, p<.001$; $\eta^{2}=.242$ ). Regarding the purge index, weight-related sport participants only significantly differed from not-weightrelated sport participants in using more purging methods $\left(p<.01, p=.259 ; \eta^{2}=.063\right)$. Finally, confirming our third hypothesis, weight-related sport participants had lower selfesteem than not-weight-related sport participants and nonparticipants $\left(p<.01, p<.05 ; \eta^{2}=.065\right)$.

\section{Discussion}

The main purpose of the present study was to examine the relationship between weight-related motivations and disordered eating indices in adolescent girls outside the area of fitness centers. In particular, we investigated the relationships of weight-related sport participation and body image, dieting behaviors, and self-esteem in a general sample of 13-18 years old girls. Our sample included $82.9 \%$ sport participants, which is in line with recent statistics of the Dutch population indicating that $86 \%$ of the adolescent women between 12-19 years of age participate in sport (Breedveld and Tiessen-Raaphorst 2006).

Other American and Australian studies already concluded that adolescent women worry deeply about weight and body image issues and attempt to lose weight by exercise or other methods (e.g. Middleman and Durant 1996; Middleman et al. 1998; Nowak 1998). Indeed, it is during adolescence that girls gain more fat, which takes them away from the lean female idealized body figure (Striegel-Moore et al. 1986). Our study in a Dutch female adolescent sample seems to confirm these results since $28.6 \%$ of the girls were classified as "weight-related sport participants" as they reported regular weekly participation in sport or exercise for weight-related motives. These numbers put in perspective the results of Waldherr et al. (2008) that Dutch girls seem to have the least disordered eating related issues, and show that weight preoccupation among girls in the Netherlands is not just marginally present.

When compared to not-weight-related sport participants and girls not participating in sport, weight-related sport participants were slightly older and had a higher, yet normal and healthy BMI, therefore age and BMI were included as covariates in subsequent analyses. Whereas no significant effects were found for covariate age, significant effects were found on various dependent variables for BMI. In line with our hypotheses, having weight-related motives for sport participation appeared to have several negative associations with body image, dieting behaviors and self-esteem. Even when controlling for actual body composition (BMI) and age, weightrelated sport participants perceived themselves as more fat, were more dissatisfied with their body figure, and perceived their body (but not their face) as less beautiful than not-weightrelated sport participants and non-participants. In addition, they reported higher dieting frequency, used more weight control and purging methods, and had lower self-esteem.

These results are in agreement with the results from other studies on body-related motivation in older adolescent or adult samples of regular exercisers and fitness participants (e.g. Cash et al. 1994; Ingledew and Sullivan 2002; McDonald and Thompson 1992, Silberstein et al. 1988; Smith et al. 1998; Strelan et al. 2003; Tiggemann and Williamson 2000). It seems that female sport participants in general often have weight-related motives for their sport participation that are accompanied by body dissatisfaction, weight control, and lower self-esteem. It can now be concluded that this is also applicable to younger female adolescents below 16 years of age. Our results seem to underline the importance of motives for sport participation for body image, dieting, and self-esteem that are known for their contribution to the development of either healthy or disordered eating patterns. Consequently, our results emphasize how important it is to take into account the motives for sport participation when studying relationships between sport and well being.

Obviously, we should keep in mind that there is debate in the literature about the validity and reliability of BMI as a measure for the prediction of body fat distribution in younger people due to the rapid bodily changes in adolescence (cf. Kok et al. 2004). In this respect, it is also important 
to note that in the present study BMI was measured by self-report which holds the risk of underreporting or overreporting. A review of the literature on the validity of selfreported height and weight in children and adolescents showed that height was often over-reported, whereas weight is more likely to be underreported, leading to an underestimation of the prevalence overweight and obesity (Jansen et al. 2006). Goodman et al. (2000), on the other hand, showed that correlations between measured and self-reported anthropomorphic indices in an adolescent sample were very strong with $r=.92$ for body mass index. Davis (1990) concluded that self-report is more accurate when the anonymity of the respondents is guaranteed, as was the case in the present study. Still, future studies should also aim at replicating our findings with actual measures of anthropometric variables.

A limitation in the current study was the use of some oneitem measures. Yet, this is more common in recent studies investigating eating behaviors (e.g., Harrell and Jackson 2008), and studies that are part of a larger research project (e.g., Wardle et al. 2006). In the present study, strong correlations existed between our one-item measures with related measures, for example, between the one-item measure of perceived body shape and the body figure discrepancy score of the Contour Drawing Rating Scale, which inspired our confidence in the use of these one-item measures. Needless to say, if possible, future studies should consider using full questionnaires. This also holds for the relatively crude index scores for weight control and purging with a somewhat limited reliability (Nunnally 1978). In future studies focusing exclusively on relationships between motivation for sport and exercise and disorded eating, a more extensive measure, such as the Eating Disorder Examination Questionnaire (EDE-Q, Fairburn and Beglin 1994), could be administered which should also lead to improved reliability coefficients (Mond et al. 2004). Future studies could also incorporate a more extensive measure for the motivation of sport and exercise, such as the Exercise Motivation Inventory-2 (EMI-2, Markland and Ingledew 1997) that acknowledges the existence of multiple sports motives. In the present study, we just focused on a weight-related motivation, because reasons such as burning calories and weight control appeared to be associated with the greatest disturbance on disordered eating indices (Hubbard et al. 1998). In the subgroup weight-related sport participants, we included only those girls for whom weight-related sport participation was a recent, frequent, and repetitive activity by using the criterion of a weekly frequency. In doing so, it was assumed that we justly excluded the girls to whom other sport motives were more important. By administering the Exercise Motivation Inventory-2 (EMI-2, Markland and Ingledew 1997), in addition to our dichotomous measure of a weight-related motive, these assumptions could be made more explicit and the relationships between being motivated by weight management and other (more functional) motives would become clear.

It should also be noted that our design was only correlational in nature. Instead of weight-related motives leading to body dissatisfaction which in turn leads to weight control behaviors, it is also possible that girls who are dissatisfied with their weight and body, choose to engage in exercise or sport and other weight control behaviors in order to lose weight. Although it is tempting to think that the latter is perhaps more obvious, the study of Strelan et al. (2003) clearly showed that body-related exercise motives acted as a mediating variable accounting for the reduced body satisfaction and self-esteem of self-objectifying women and girls. Future studies should focus on this issue of causality by investigating the process through which weight-related motives for sport participation exert their influence.

Finally, future research could also focus on body-related exercise or sport participation of men, since physical activity to gain weight, strength and/or muscle mass seems common in men, and relationships with phenomena such as muscle dysmorphia, disordered eating and substance abuse are prevalent in certain male populations (e.g., Pope et al. 2000).

In conclusion, many adolescent girls seemed to choose the sport environment or fitness centers in search for a solution for their alleged overweight. Yet, it should be noted that nearly all girls with a weight-related motive for sport participation had a normal and healthy body composition according to their BMI. However, as associations of weight-related motive with body dissatisfaction and low self-esteem also existed after controlling for BMI, it is very unlikely that these weight-related sport activities will ever be a solution for their unhappiness with themselves. Special attention is warranted for the fact that the girls who exercised for weight control reported having used unhealthy weight control methods such as fasting, selfinduced vomiting and the use of diuretics/diet pills significantly more often. These results are in agreement with those of Nowak (1998) who concluded that in weight-conscious girls exercising was accompanied by unhealthy eating patterns. For these girls, sport participation does not seem to translate into increased body image and self-esteem as it does in general populations (Strelan et al. 2003). Seeing that a weight-related motive for sport and exercise clearly seems to hold a risk for developing psychological problems, even for younger girls from the age of 13 years old, it is important for sport coaches, trainers, exercise instructors, and physical education teachers to identify these girls at an early stage. Shaffer and Wittes (2006) already concluded that sport participation only leads to an increase in self-esteem if the participants enjoy their sports experience. Hence, it seems sensible for coaching and training staff in sports or exercise as well as for policy makers and public authorities to emphasize enjoyment and other, not-weight-related motives for sport participation. 


\section{Appendix Lichaamsbeeldvragenlijst (Woertman 1994-korte versie)}

Hieronder volgt een aantal vragen. Lees iedere vraag en de daarbij horende (invul)instructie goed. Vul het antwoord in dat het beste bij je past. Er zijn geen goede of slechte antwoorden. Denk niet te lang na en geef je eerste indruk, die is meestal de beste. Vul alle vragen in en houd je aan de volgorde van de vragenlijst. Je antwoorden blijven gegarandeerd anoniem.

1. Lengte: $\quad$..... centimeter

2. Huidige gewicht: $\quad . . .$. kilo

3a. Aan welke sport(en) doe je?

(NB: denk hierbij aan sporten in je vrije tijd en NIET aan de gymlessen op school)

Hoofdsport:

Andere:

3b. Hoeveel uren besteed je per week gemiddeld aan trainingen en wedstrijden? uren per week

3c. Ik beschouw mijn hoofdsport als:

Topsport / wedstrijdsport / recreatiesport ${ }^{*}$

Omcirkel het antwoord dat het beste bij je past.

9. Wat vind je van je gezicht:

$\begin{array}{llllllllll}\text { niet mooi } & 1 & 2 & 3 & 4 & 5 & 6 & 7 & 8 & 9\end{array}$

10. Wat vind je van de rest van je lichaam:

$\begin{array}{lllllllllll}\text { niet mooi } & 1 & 2 & 3 & 4 & 5 & 6 & 7 & 8 & 9 & \text { mooi }\end{array}$

11. Vind je je lichaam:

$\begin{array}{lllllllllll}\text { te dun } & 1 & 2 & 3 & 4 & 5 & 6 & 7 & 8 & 9 & \text { te dik }\end{array}$

12. Vind je je lichaam:

$\begin{array}{lllllllllll}\text { te klein } & 1 & 2 & 3 & 4 & 5 & 6 & 7 & 8 & 9 & \text { te groot }\end{array}$

13. Doe je aan de lijn?

$\begin{array}{lllllllllll}\text { nooit } & 1 & 2 & 3 & 4 & 5 & 6 & 7 & 8 & 9 & \text { altijd }\end{array}$

14. Hoeveel zou je willen wegen? ..... kilo

15. Het beeld dat je van je gezicht hebt, is:

$\begin{array}{lllllllllll}\text { negatief } & 1 & 2 & 3 & 4 & 5 & 6 & 7 & 8 & 9 & \text { positief }\end{array}$

16. Het beeld dat je van de rest van je lichaam hebt, is:

$\begin{array}{lllllllllll}\text { negatief } & 1 & 2 & 3 & 4 & 5 & 6 & 7 & 8 & 9 & \text { positief }\end{array}$

17. Jongens vinden mijn gezicht:

$\begin{array}{lllllllllll}\text { niet mooi } & 1 & 2 & 3 & 4 & 5 & 6 & 7 & 8 & 9 & \text { mooi }\end{array}$

18. Jongens vinden mijn lichaam:

$\begin{array}{lllllllllll}\text { niet mooi } & 1 & 2 & 3 & 4 & 5 & 6 & 7 & 8 & 9 & \text { mooi }\end{array}$


19. Meiden vinden mijn gezicht:

niet mooi 11223

4

5

20. Meiden vinden mijn lichaam:

$\begin{array}{lllllllllll}\text { niet mooi } & 1 & 2 & 3 & 4 & 5 & 6 & 7 & 8 & 9 & \text { mooi }\end{array}$

21. Welk rapportcijfer (van $1 \mathrm{t} / \mathrm{m}$ 10) geef je aan: je gezicht

je lichaam

De volgende vragen gaan over de manier waarop je bezig bent met voeding en je

lichaamsgewicht. Antwoord zo eerlijk mogelijk. Je antwoorden blijven gegarandeerd

anoniem.

28. Heb je ooit ongecontroleerde vreetbuien gehad waarbij je erg grote hoeveelheden voedsel in zeer korte tijd hebt gegeten?

$\square$ ja $\square$ nee

Zo ja, hoe vaak in de afgelopen drie maanden?

keer per dag/week/maand ${ }^{*}$

29. Heb je ooit gesport of getraind met het specifieke doel om calorieën te verbranden of gewicht kwijt te raken / controleren?

$\square$ ja $\square$ nee

Zo ja, hoe vaak in de afgelopen drie maanden? uren per dag/week/maand ${ }^{*}$

30. Heb je ooit gevast of je aan een streng dieet gehouden om gewicht kwijt te raken?

$\square$ ja $\square$ nee

Zo ja, hoe vaak in de afgelopen drie maanden? keer per dag/week/maand ${ }^{*}$

31. Heb je ooit bewust braken opgewekt vlak na de maaltijd om het gegeten voedsel zo snel mogelijk weer kwijt te raken?

$\square$ ja $\square$ nee

Zo ja, hoe vaak in de afgelopen drie maanden? keer per dag/week/maand ${ }^{*}$

32. Heb je ooit afslankmiddelen of vochtafdrijvende middelen (diuretica, plaspillen) gebruikt om gewicht kwijt te raken?

$\square$ ja $\square$ nee

Zo ja, hoe vaak in de afgelopen drie maanden? keer per dag/week/maand*

33. Heb je ooit laxeermiddelen of zetpillen gebruikt om gewicht kwijt te raken?

$\square$ ja $\square$ nee

Zo ja, hoe vaak in de afgelopen drie maanden? keer per dag/week/maand ${ }^{*}$

* Doorhalen wat niet van toepassing is.

English translation Multidimensional Body Image Questionnaire (Woertman, 1994)

Below, we will ask you a number of questions. Read each question carefully, as well as the accompanying instructions on how to complete the question. Give the answer that fits you best. There are no correct or incorrect answers. Don't think too long about your answer; just give your first impression, which is often the best. Complete all questions and stick to the order of the questionnaire. We will guarantee that your answers will stay anonymous. 
1. Height: centimeter

2. Current weight: ..... kilo

3a. In which sport(s) do you participate? ${ }^{\mathrm{a}}$

(NB: think about sport participation in your leisure time and do NOT include physical education lessons at school)

Main sport:

Side sport(s):

3b. How many hours a week do you spend on average on training and competitions? hours a week

3c. I consider the level of my main sport to be:

Elite sport / competitive sport / recreational ${ }^{*}$

Encircle the answer that fits you best.

9. How do you think/feel about your face: ${ }^{c}$

$\begin{array}{llllllllllll}\text { not beautiful } & 1 & 2 & 3 & 4 & 5 & 6 & 7 & 8 & 9 & \text { beautiful }\end{array}$

10. How do you think/feel about the rest of your body: ${ }^{\mathrm{c}}$

$\begin{array}{lllllllllll}\text { not beautiful } & 1 & 2 & 3 & 4 & 5 & 6 & 7 & 8 & 9 & \text { beautiful }\end{array}$

11. Do you think/feel your body is: ${ }^{\mathrm{c}}$

$\begin{array}{lllllllllll}\text { too thin } & 1 & 2 & 3 & 4 & 5 & 6 & 7 & 8 & 9 & \text { too fat }\end{array}$

13. Are you trying to lose weight? ${ }^{\mathrm{d}}$

$\begin{array}{lllllllllll}\text { never } & 1 & 2 & 3 & 4 & 5 & 6 & 7 & 8 & 9 & \text { always }\end{array}$

14. What is your desired weight? $\quad$..... kilo

15. The image you have of your face is:

$\begin{array}{llllllllllll}\text { negative } & 1 & 2 & 3 & 4 & 5 & 6 & 7 & 8 & 9 & \text { positive }\end{array}$

16. The image you have of the rest of your body is:

$\begin{array}{lllllllllll}\text { negative } & 1 & 2 & 3 & 4 & 5 & 6 & 7 & 8 & 9 & \text { positive }\end{array}$

17. Boys think my face is: ${ }^{\mathrm{c}}$

$\begin{array}{lllllllllll}\text { not beautiful } & 1 & 2 & 3 & 4 & 5 & 6 & 7 & 8 & 9 & \text { beautiful }\end{array}$

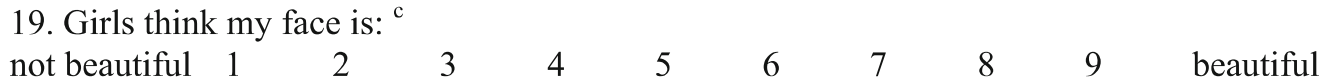

20. Girls think my body is: ${ }^{\mathrm{c}}$

$\begin{array}{lllllllllll}\text { not beautiful } & 1 & 2 & 3 & 4 & 5 & 6 & 7 & 8 & 9 & \text { beautiful }\end{array}$

21. How would you mark (from 1 to 10$)^{\mathrm{e}}$ : your face $\quad \ldots$ your body 
The next questions are concerned with how you are dealing with food and body weight.

Please answer honestly. We guarantee that your answers will stay anonymous.

29. Did you ever participate in sport or exercise with the specific purpose of burning extra calories or losing weight? ${ }^{\mathrm{a}}$

$\square$ yes $\square$ no

If so, how often did this occur in the past three months? times a day/week/month

30. Did you ever fast or comply with a strict diet to lose weight?

$\square$ yes $\square$ no

If so, how often did this occur in the past three months? times a day/week/month ${ }^{*}$

31. Did you ever use self-induced vomiting just after your meal to get rid of the food you ate as quickly as possible, in order to lose weight?

$\square$ yes $\square$ no

If so, how often did this occur in the past three months? times a day/week/month ${ }^{*}$

32. Did you ever use diet pills or diuretics to lose weight?

$\square$ yes $\square$ no

If so, how often did this occur in the past three months? times a day/week/month ${ }^{*}$

33. Did you ever use laxatives or suppositories to lose weight?

$\square$ yes $\square$ no

If so, how often did this occur in the past three months? times a day/week/month

* Cross out what is not applicable.

Note. The current study was part of a larger study. Only the measurements of weight characteristics, body image and weight control behaviors that are reported in the current manuscript are included in the appendix.

a The Dutch verbs 'sporten' and 'trainen' refer to a range of physical activities including sport participation as well as exercise. For example, visiting a fitness center is commonly expressed in Dutch as going to the 'sportschool'.

${ }^{\mathrm{b}}$ Participants were given explicit scoring instructions in the class room, such as that they could choose every digit and how to interpret the score 5 in the subsequent items 9 to 20 .

' The Dutch verb 'vinden' refers to both to think and to feel.

d The Dutch verb 'aan de lijn doen' or 'lijnen' is translated with to slim or to diet; in other words it refers to losing weight in general and not just to dieting.

${ }^{\mathrm{e}}$ In the Dutch school system, report marks vary between 1 (very bad) to 10 (excellent). 
Open Access This article is distributed under the terms of the Creative Commons Attribution Noncommercial License which permits any noncommercial use, distribution, and reproduction in any medium, provided the original author(s) and source are credited.

\section{References}

Blascovich, J., \& Tomaka, J. (1993). Measures of self-esteem. In J. P. Robinson, P. R. Shaver, \& L. S. Wrightsman (Eds.), Measures of personality and social psychological attitudes (pp. 115-160, 3rd ed.). Ann Arbor: Institute for Social Research.

Breedveld, K., \& Tiessen-Raaphorst, A. (2006). Rapportage sport 2006. [Sport report 2006]. Den Haag: Sociaal en Cultureel Planbureau.

Cash, T. F., Novy, P. L., \& Grant, J. L. (1994). Why do women exercise? Factor analysis and further validation of the Reasons for Exercise Inventory. Perceptual and Motor Skills, 78, 539-544.

Crissey, S. R., \& Crissey Honea, J. (2006). The relationship between athletic participation and perceptions of body size and weight control in adolescent girls: the role of sport type. Sociology of Sport Journal, 23, 248-272.

Davis, C. (1990). Body image and weight preoccupation: a comparison between exercising and non-exercising women. Appetite, 15, 13-21.

De Bruin, A. P., Oudejans, R. D. D., \& Bakker, F. C. (2007). Dieting and body image in aesthetic sports: a comparison of Dutch female gymnasts and non-aesthetic sport participants. Psychology of Sport and Exercise, 8, 507-520.

DiBartolo, P. M., \& Shaffer, C. (2002). A comparison of female college athletes and nonathletes: eating disorder symptomatology and psychological well-being. Journal of Sport \& Exercise Psychology, 24, 33-41.

Engel, S. G., Johnson, C., Powers, P. S., Crosby, R. D., Wonderlich, S. A., Wittrock, D. A., et al. (2003). Predictors of disordered eating in a sample of elite Division I college athletes. Eating Behaviors, 4, 333-343.

Fairburn, C. G., \& Beglin, S. J. (1994). Assessment of eating disorders: interview or self-report questionnaire? The International Journal of Eating Disorders, 16, 363-370.

Frederick, C. M., \& Ryan, R. M. (1993). Differences in motivation for sport and exercise and their relations with participation and mental health. Journal of Sport Behavior, 16, 124-146.

Fredrickson, B. L., \& Roberts, T.-A. (1997). Objectification theory: toward understanding women's lived experience and mental health risks. Psychology of Women Quarterly, 21, 173-206.

Furnham, A., Badmin, N., \& Sneade, I. (2002). Body image dissatisfaction: gender differences in eating attitudes, self-esteem and reasons for exercise. The Journal of Psychology, 136, 581-596.

Gardner, R. M. (2001). Assessment of body image disturbance in children and adolescents. In J. K. Thompson, \& L. Smolak (Eds.), Body image, eating disorders and obesity in youth: assessment, prevention and treatment (pp. 193-213). Washington, DC: American Psychological Association.

Goodman, E., Hinden, B. R., \& Khandelwal, S. (2000). Accuracy of teen and parental reports of obesity and body mass index. Pediatrics, 106, 52-58.

Harrell, Z. A. T., \& Jackson, B. (2008). Thinking fat and feeling blue: eating Behaviors, ruminative coping, and depressive symptoms in college women. Sex Roles, 58, 658-665.

Hausenblas, H. A., \& Symons-Downs, D. (2001). Comparison of body image between athletes and nonathletes: a meta-analytic review. Journal of Applied Sport Psychology, 13, 323-339.

Hausenblas, H. A., \& Fallon, E. A. (2006). Exercise and body image: a meta-analysis. Psychology \& Health, 21, 33-47.
Hirasing, R. A., Fredriks, A. M., Van Buuren, S., Verhoove-Vanhorick, S. P., \& Wit, J. M. (2001). Increased prevalence of overweight and obesity in Dutch children, and the detection of overweight and obesity using international criteria and new reference diagrams. Nederlands Tijdschrift voor Geneeskunde, 145, 1303-1308.

Hubbard, S. T., Gray, J. J., \& Parker, S. (1998). Differences among women who exercise for food-related and non-food related reasons. European Eating Disorders Review, 6, 255-265.

Ingledew, D. K., \& Sullivan, G. (2002). Effects of body mass and body image on exercise motives in adolescence. Psychology of Sport and Exercise, 3, 323-338.

Jacobi, C., Hayward, C., de Zwaan, M., Kraemer, H. C., \& Agras, W. S (2004). Coming to terms with risk factors for eating disorders: application of risk terminology and suggestions for a general taxonomy. Psychological Bulletin, 130, 19-65.

Jansen, W., van der Looij-Jansen, P. M., Ferreira, I., de Wilde, E. J., \& Brug, J. (2006). Measured and self-reported height and weight in Dutch adolescents. Annals of Nutrition \& Metabolism, 50, 339-346.

Killen, J. D., Taylor, C. B., Hayard, C., Haydel, K. F., Wilson, D. M., Hammer, L., et al. (1996). Weight concerns influence the development of eating disorders: a 4-year prospective study. Journal of Consulting and Clinical Psychology, 64, 939-940.

Klomsten, A. T., Skaalvik, E. M., \& Espnes, G. A. (2004). Physical self-concept and sports: do gender differences still exist? Sex Roles, 50, 119-127.

Kok, P., Seidell, J. C., \& Meinders, A. E. (2004). The value and limitations of the use of body mass index (BMI) in the assessment of the health risks of overweight and obesity. Nederlands Tijdschrift voor Geneeskunde, 148, 2379-2383.

Loland, N. W. (1998). Body image and physical activity. A survey among Norwegian men and women. International Journal of Sport Psychology, 29, 339-365.

Markland, D., \& Ingledew, D. K. (1997). The measurement of exercise motives: factorial validity and invariance across gender of a revised Exercise Motivations Inventory. British Journal of Health Psychology, 2, 361-376.

McDonald, K., \& Thompson, J. K. (1992). Eating disturbance, body image dissatisfaction, and reasons for exercising: gender differences and correlational findings. The International Journal of Eating Disorders, 11, 289-292.

Middleman, A. B., \& Durant, R. H. (1996). Factors associated with attempting to lose weight among adolescents. The Journal of Adolescent Health, 18, 138.

Middleman, A. B., Vazquez, I., \& Durant, R. H. (1998). Eating patterns, physical activity and attempts to change weight among adolescents. The Journal of Adolescent Health, 22, 37-42.

Mond, J. M., Hay, P. J., Rogers, B., Owen, C., \& Beumont, P. J. (2004). Validity of Eating Disorder Examination Questionnaire in screening for eating disorders in community samples. Behaviour Research and Therapy, 42, 551-567.

Nowak, M. (1998). The weight-conscious adolescent: body Image, food intake and weight-related behavior. The Journal of Adolescent Health, 23, 389-398.

Nunnally, J. C. (1978). Psychometric theory (2nd ed.). New York: McGraw-Hill.

Pallant, J. (2005). SPSS survival manual (2nd ed.). Maidenhead: Open University Press.

Pope, H. G., Phillips, K. A., \& Olivardia, R. (2000). The Adonis complex: How to identify, treat, and prevent body obsession in men and boys. New York: Touchstone.

Prichard, I., \& Tiggemann, M. (2005). Objectification in fitness centers: self-objectification, body dissatisfaction, and disordered eating in aerobic instructors and aerobic participants. Sex Roles, $53,19-28$

Rosenberg, M. (1989). Society and the adolescent self-image (Rev. ed.). Middletown, CT: Wesleyan University Press. 
Sassatelli, R. (1999). Interaction order and beyond: a field analysis of body culture within fitness gyms. Body \& Society, 5, 227-248.

Shaffer, D. R., \& Wittes, E. (2006). Women's precollege sports participation, enjoyment of sports and self-esteem. Sex Roles, 55, 225-232.

Shisslak, C. M., \& Crago, M. (2001). Risk and protective factors in the development of eating disorders. In J.K. Thompson, \& L. Smolak (Eds.), Body image, eating disorders and obesity in youth: Assessment, prevention and treatment (pp. 103-125). Washington, DC: American Psychological Association.

Silberstein, L. R., Striegel-Moore, R. H., Timko, C., \& Rodin, J. (1988). Behavioral and psychological implications of body dissatisfaction: do men and women differ? Sex Roles, 19, 219-232.

Smith, B. L., Handley, P., \& Eldredge, D. A. (1998). Sex differences in exercise motivation and body image satisfaction among college students. Perceptual and Motor Skills, 86, 723-732.

Smolak, L., Murnen, S. K., \& Ruble, A. E. (2000). Female athletes and eating problems: a meta-analysis. The International Journal of Eating Disorders, 27, 371-380.

Strelan, P., Mehaffey, S. J., \& Tiggemann, M. (2003). Selfobjectification and esteem in young women: the mediating role for reasons of exercise. Sex Roles, 85, 89-95.

Striegel-Moore, R. H., Silberstein, L. R., \& Rodin, J. (1986). Toward an understanding of risk factors for bulimia. The American Psychologist, 41, 246-263.

Sundgot-Borgen, J., \& Torstveit, M. K. (2004). Prevalence of eating disorders in elite athletes is higher than in the general population. Clinical Journal of Sport Medicine, 14, 25-32.

Thelen, M. H., Farmer, J., Wonderlich, S., \& Smith, M. (1991). A revision of the bulimia test: the Bulit-R. Psychological Assessment. Journal of Consulting and Clinical Psychology, 3, 199-124.
Thompson, M., \& Gray, M. (1995). Development and validation of a new body-image assessment scale. Journal of Personality Assessment, 64, 258-269.

Tiggemann, M., \& Williamson, S. (2000). The effect of exercise on body satisfaction and self-esteem as a function of gender and age. Sex Roles, 43, 119-127.

Torstveit, M. K. (2004). The female athlete triad in Norwegian elite athletes and non-athletic controls. Identification and prevalence of disordered eating, menstrual dysfunction and osteoporosis. Dissertation from the Norwegian University of Sport and Physical Education.

Van Hilvoorde, I. (2008). Fitness: the early (Dutch) roots of a modern industry. The International Journal of the History of Sport, 25, 1306-1325.

Van Strien, T., \& Ouwens, M. (2003). Validation of the Dutch EDI-2 in one clinical and two non-clinical populations. European Journal of Psychological Assessment, 19, 66-84.

Vincent, M. A., McCabe, M. P., \& Ricciardelli, L. A. (1999). Factorial validity of the Bulimia-Test Revised in adolescent boys and girls. Behaviour Research and Therapy, 37, 1129-1140.

Waldherr, K., Favaro, A., Santonastaso, P., Van Strien, T., \& Rathner, G. (2008). Comparison of the Eating Disorder Inventory (EDI) in the Netherlands, Austria and Italy. European Eating Disorders Review, 16, 472-479.

Wardle, J., Haase, A. M., \& Steptoe, A. (2006). Body image and weight control in young adults: international comparisons in university students from 22 countries. Journal of Obesity, 30, 644-651.

Woertman, L. (1994). Beelden van een lichaam. Mentale representaties van lichaamsbeelden. [Images of a body. Mental representations of body images]. Lisse: Swets and Zeitlinger. 